\title{
THE PAROL EVIDENCE RULE AS A PRO- CEDURAL DEVICE FOR CONTROL OF * THE JURY
}

\section{CHARLES T. MICORMITK}

A MIR. SWARTWOod was the president of a corporation engaged in the business of running a flour mill. In 1919 the company's credit became shaky. To enable it to secure grain for its business, Mr. Swartwood entered into a written contract with a grain commission house, whereby he guaranteed the payment of "any and all sums of money" requested by the corporation and furnished by the commission house, until further notice. Large sums were furnished. The corporation later became bankrupt, and a balance of $\$ 10,000$ for these advances remained unpaid. The commission house sued Mr. Swartwood upon his guaranty, and he contended that it was orally agreed, at the time, that the guaranty should apply only to sums furnished for the purchase of grain by the milling company locally, at the small town where its mill and elevator were situated, whereas the sums sued for were advanced for purchases of grain in the Minneapolis market, to be shipped to the mill. At the trial, a jury accepted this contention, and judgment followed that the plaintiff take nothing from Mr. Swartwood. To the appellate court, however, $\mathrm{MTr}$. Swartwood's defense was quite unacceptable, because of the "rule which prevents the destruction of the obligation of a written contract by evidence of preceding or contemporaneous oral agreements." Significantly, the court added: "Without that rule there would be no assurance of the enforceability of a written contract. If such assurance were removed today from our law, general disaster would result, because of the consequent destruction of confidence, for the tremendous but closely adjusted machinery of modern business cannot function at all without confidence in the enforceability of contracts." 1

The court assumes as self-evident that without some special assurance of the enforcement of contracts as written, as against claims of inconsistent oral agreements, business men generally will be seriously handicapped in the prosecution of commercial enterprise. Like most of the law's basic assumptions, this one

\footnotetext{
* Professor of Law, Northwestern University School of Law; author of The Borderland of Hearsay (1930) 39 YaLe L. J. 489.

1 Cargill Commission Co. v. Swartwood, 159 Minn. 1, 7, 198 N. W. 536, 538 (1924).
} 
has never been tested by any survey of the actual effects in business of the presence or absence of such assurance." But there can be little doubt that a belief in the soundness of this apprehension has been one of the chief motives of judges in the development and preservation of the nexus of doctrines called by the name of the Parol Evidence Rule. Despite the probable importance to the business world of some reliable guaranties of the integrity of written transactions, the difficulties in extending such protection are apparent in a country where, by law and common habit, nearly all kinds of agreements may be oral, and where disputed fact-claims are ordinarily left to the arbitrament of a group of twelve men, not selected for any specinl competence for the task of judging.

When an issue arises involving choice between a writing and an alleged oral agreement, usually the one who sets up the spoken against the written word is economically the under-dog. Ho may be a person who has signed a note at the bank for himself or his neighbor and who asserts that it was agreed that the note or endorsement should not be enforced until certain funds should be realized by the debtor, or he may be a farmer who has purchased a tractor on credit and who resists collection on the ground that the agent of the tractor company orally warranted the power-rating of the tractor in a way not specified in the written sales agreement. The types of transaction wherein is involved this kind of competition between claims based upon writings and those based upon alleged oral agreements dealing with the same affair, are infinitely various, but usually if there is a difference between the two parties in economic status, the one who relies upon the writing is likely to be among the "haves," and the one who seeks escape through the oral word will probably be ranged among the "have nots," in Sincho Panza's classification. The average jury will, other things being equal, lean strongly in favor of the side which is threatened with possible injustice and certain hardship by the enforcement of the writing.

"The written word remains," a genuine and veracious memorial, so far as it goes, of what was actually agreed to. On the other hand, the narrative by a witness of the purported substance of words, spoken many months or even years before, is

\footnotetext{
2 It would, perhaps, be worth while to canvass the managers and counsol of business enterprises of country-wide scope, to ascertain whethor thoy are aware of the lack of strictness of the courts of a few of the states (a.g., North Carolina) in protecting writings against claimed oral agreements, and, if so, whether this influences the amount and methods of business done by them in those states. Local studies of the operation of the rulo aro Dean W. G. Hale's excellent article, The Parol Evidenco Rulo (1925) 4 OnE. L. REv. 91; and Chadbourn and McCormick, The Parol Evidenco Rulo in North Carolina (1931) 9 N. C. L. REv. 151.
} 
subject to a very high probability of error, ${ }^{3}$ even when recounted by a disinterested person. It is doubtful whether a jury is likely to take sufficient account of this factor of unreliability. Noreover, the witness who recounts the oral bargaining seldom is, in fact, disinterested. He is usually the party himself, who is struggling, honestly or dishonestly, to escape the hardship of the terms nominated in the bond." The struggle is all too often, consciously or unconsciously, the father of the recollected conversation. From all these sources springs grave danger that honest expectations, based upon carefully considered written transactions, may be defeated through the sympathetic, if not credulous, acceptance by juries of fabricated or wish-borm oral agreements. ${ }^{5}$ Likewise, some peril to justice and to the stability of business transactions lies in the possibility that earlier and tentative oral agreements which were a part of the preliminary - parleying, but were actually understood by both parties to be abandoned when omitted in the final witten agreement, will be stoutly asserted by one party at the trial as having been intended to stand alongside the writing. When a genuine, but superseded, oral agreement is thus set up, it will be even harder for the jury to reject the claim based on such agreement than if it were fabricated from the whole cloth.

The danger of undermining confidence in witten bargains generally is one which can be appreciated by a trial judge, who looks back on many similar cases and is trained to take a long view. MIoreover, he is likely, during his practice, to have imbibed some understanding from his clients of the needs of business, and to know from extended observation how to discount testi-

\footnotetext{
${ }^{3}$ Coke reports Popham, C. J., as saying, in the Countess of Rutland's case: "Also it would be inconvenient that matters in writing made by advice and on consideration, and which finally import the certain truth of the agreement of, the parties, should be controlled by averment of the parties, to be proved by the uncertain testimony of slippery memory." 3 Co. 51 (1604).

4 It is possible that the protection which it afforded to writings may hare served to lengthen the life of the archaic and irrational rule which disqualified parties from testifying.

5 To recognize these dangers is not to overlook the corresponding dangers on the other tack. When a written contract has, after lengthy negotiations, been prepared for signing, and a term orally agreed upon has been omitted or distorted by the scrivener, an oral assurance that "it will be all right" may often serve to gloss the matter over to a signature, especially where the contingency provided for in the oral understanding scems remote. The party may hesitate to delay matters by insisting on having the writing amended. Especially is this true today, when many transactions are consummated by standardized printed contracts. These are tendered by agents who are often instructed by their principals not to permit the written forms to be altered, even when, as so often happens, they do not fit exactly the individual requirements of the customer. Cf. Llewellyn, What Price Contract? (1931) 40 YALE L. J. 704, 747.
} 
mony for the warping of self-interest. The jury, on the other hand, is likely to pass over these considerations in its urge of sympathy for a party whom the shoe of the written contract pinches. This sympathy may occasionally deflect even the decision of the trial judge who sees, and often personally knows, the harassed party. The appellate judge, remote from local acquaintance and local political interest, is free to adopt a still closer approach to the Jovian detachment of the "long view."

The continental legal system, with no civil jury, and with most contracts required to be entirely in writing, has little trouble in guarding written bargains from oral encroachment. This danger to written transactions is peculiarly inherent in the common-law methods of trial. How did the common-law judges make provision against this danger, which, as we have seen, flows chiefly from the peculiar institution of the untrained jury, a body numerous enough to invite emotional organ-playing by counsel, and usually unguided in this country by any specific advice from the trial judge? The danger from allowing juries to do their worst with written transactions was doubtless sensed intuitively by the judges, ${ }^{b}$ but this was prevented from emerging into consciousness and expression by the prevailing idolatry, sincerely enough entertained by the judges themselves, of the jury as a symbol of political liberty. ${ }^{7}$ Otherwise, they might frankly have reserved for the judge's decision (as one of the exceptions to the general practice) the question of fact as to

6 That the parol evidence rule chiefly stems from an anxiety to protect written bargains from re-writing by juries, is confirmed by the comparitive freedom which was allowed in chancery in respect to reformation, and in regard to oral variations asserted as a ground for denying specific performance. Of the latter, a recent example is John T. Stanley Co., Inc. v. Lagomarsino, 49 F. (2d) 702 (C. C. A. 2d, 1931). It is true that other doors for jury intervention in support of oral variations have not boen closed, as in the case of oral agreements that the writing shall not go into effect until the happening of a condition, and likewise oral agreoments modifying the written terms after the execution of the document. Each of these escapes from the writing presents difficulties to the one who attempts it, and, in any event, the fact that protection in some situations has not been perfect, does not disprove the desire to furnish it generally.

$\tau$ Mr. Justice Blackstone, for example, in his Commentaries (3 BL. Comm. $294, * 379$ ), begins his eulogy thus: "Upon these accounts the trial by jury ever has been, and I trust ever will be, looked upon "as the glory of the English law. ... It is the most transcendent privilege which any subject can enjoy, or wish for, that he cannot be affected either in his property, his liberty, or his person, but by the unanimous consent of twelve of his neighbours and equals. A constitution, that I may venture to affirm has, under Providence, secured the just liberties of this nation for a long succession of ages. And therefore a celebrated French writer (Montesq. Sp. L. xi. 6), who concludes, that because Rome, Sparta, and Carthage havo lost their liberties, therefore those of England in time must perish, should have recollected that Rome, Sparta, and Carthage, at the time when their liberties were lost, were strangers to the trial by jury." 
whether an alleged oral agreement set up in competition with a writing, was actually made, and, if so, whether it was intended to be abandoned or to survive, when the writing was signed. Forbidden this straight path by their own preconceptions, by a zig-zag route they came out near the same goal. The approach was made through doctrinal devices which gave no hint of any departure from the usual division of functions between judge and jury, but which were subtly convenient for jury control in cases where written transactions were threatened by claims of agreed oral variations not credited by the judge. ${ }^{3}$

In the first place, they said, "Parol evidence is inadmissible to vary, contradict, or add to the terms of a written instrument." The phrase becomes a shibboleth, repeated in ten thousand cases. It obviously enables the judge to head off the difficulty at its source, not by professing to decide any question as to the credibility of the asserted oral variation, but by professing to exclude the evidence from the jury altogether because forbidden by a mysterious legal ban. An alternative device to the same end was the use of the formula that when a writing (variously qualified) is executed, it is "conclusively presumed" to embody the whole agreement. If conclusively presumed, then, of course, no evidence of additional oral agreements can be heard. This all-inclusive prohibition by rule of law against any competition of oral agreements with witten was effective enough as a jury-excluding formula, but as an actual standard of decision for judges it was wholly illusory.

Thus, for example, some writings are obviously mere sleleton memoranda, not intended to cover all the terms agreed on, and where this is so, the oral terms must be provable, if elementary justice is to be done. But in revising the original formula against "varying, altering, or contradicting" by recognizing an exception for mere partial memoranda, or incomplete instruments, care had to be taken not to open the door to jury-determination as to whether the exception was applicable. The exception was sought to be stated in terms of the "completeness" of the writing. The writing is the "sole criterion" of its own completeness, they said, and the judge, traditionally literate and hence trained to interpret writings by inspection, ascertains whether it is

8 It is not intended to suggest that these doctrinal devices were newly invented by the judges, consciously, to meet this need, in modern times. Thayer and Wigmore have traced too clearly the origin of the parol evidence formula against "varying the writing," to a primitive formalism which attached a mystical and ceremonial effectiveness to the carta and the seal. (5 Wigmore, Evmence (2d ed. 1923) § 2426.) The writer merely ventures to submit that this formalism, abandoned elsewhere in so many areas of modern law, had here a special survival value-the escape from the jury-which led the judges to retain for writings the conception that they had a sort of magical effect of erasing all prior oral agreements. 
"complete on its face." ${ }^{o}$ Thus far the reins are still tightly held by the judges. But the doctrine of exclusive resort to the writing (even as mitigated by the exception for obviously skeleton memoranda), while useful in aiding the judges to retain command, is much too narrow to meet the actual need for recognition of reasonable and genuine oral agreements dealing with matters related to those covered by the written document, but not intended by the parties to be superseded by the writing, even though the writing, so far as appearance goes, is seemingly a formal and completed one. Two devices were used to meet this need, without opening the door to blundering by the jury in the china-shop.

First, the language devised for the obviously sketchy memoranda, to the effect that the incompleteness was to be measured by the instrument "on its face" and hence, though this was seldom mentioned explicitly, was for the judge to determine himself by inspection, was repeated. "The only criterion of the completeness of the written contract. . is the writing itself." 10 It soon became evident, however, that while the face of the writing would usually show whether it was intended as a mere memorandum, and not as a plenary instrument at all, yet a mere. inspection could never show whether a writing, full and deliberate in form, did or did not cover all the agreements ontered into by the parties about the subject-matter. Consequently, in these latter cases the door had to be opened wider if any thing at all was to come in. So the formula was revised: The writing is still the sole criterion by which to determine whether it is "complete," but it is the writing considered in the light of all the surrounding circumstances. All, that is, except one. You may consider the entire situation leading up to the signing of the writing except the most crucial of all data, $i$. $a$., the purport of the alleged agreement which has been left out of the writing. ${ }^{11}$ Of course, no trial judge has ever actually followed any such practice of barring the door to an alleged oral agreement without first asking the mysterious stranger to identify himself. Counsel will always be asked to detnil the nature of the oral agreement desired to be proved, or the evidence of its terms will be admitted de bene until a final ruling on its admissibility is made. ${ }^{12}$ The artificiality of the elaborations of

${ }^{\circ}$ Brautigam v. Dean, 85 N. J. L. 549, 556, 89 Atl. 760, 763 (1014); Thompson v. Libby, 34 Minn. 374, 26 N. W. 1 (1885).

10 Ibid. 377,26 N. W.. at 2.

11 Wheaton Roller-Mill Co. v. John T. Noye Mfg. Co., 66 Minn. 156, 160, 68 N. W. 854 (1896).

is Other courts, in revulsion from this narrow formula, that tho "completeness" of the writing is to be determined from the face of tho writing itself, have proceeded to the opposite extreme. They say that if it appoars in evidence that oral agreements were made, and not included in tho writ- 
this doctrine of what we might call "facial completeness," and its falsity as a picture of what the trial judge actually does, result from the clumsiness of "completeness" as a doctrinal vehicle. It carries very well the relatively easy cases dealing with skeleton memoranda and with contracts or conveyances where some essential or almost universally customary term is omitted from the writing. It collapses when the courts burden it with the heavy freightage of cases where the writing shows no such obvious deficiency and where the underlying doubts are whether the alleged oral agreement really was made and, if so, whether the writing was intended to displace it.

A more practical and workable expedient for the admission of oral agreements considered by the judge as probably genuine and probably intended to remain in effect alongside the writing was the importation here of the term "collateral." The word, through long usage in other connections, had acquired a rich patina of technical legalism. Consequently, it would not occur to any one to suggest the submission to a jury of the question whether an alleged oral warranty by a landlord (at the time of making a written lease) that the drains of the house were in good order, was "collateral" to the lease.13 Apparently, the idea of allowable collateral agreements has enabled judges to follow their common sense and instinct for justice by furnishing them an escape from the formula against "varying, contradicting, or adding to" the writing, when a litigant seeks to establish an oral agreement which might reasonably have been intended to stand after the writing was signed.

\section{II}

The older techniques thus far described have served several purposes fairly well. The "rule of evidence" against "varying" the writing by "parol" enabled the judge to cut out at the outset -by excluding evidence-mischievous claims of dubious oral agreements. He could thus protect investments founded on written bargains. The "exception" for "incomplete" writings, for "collateral" oral agreements, or the even wider escape-valve used by some courts of "contracts partly oral and partly writ-

ing, it then follows that the writing is "incomplete," and if incomplete, then the parol evidence rule does not apply. See Exum r. Lynch, 188 N. C. 392,125 S. E. 15 (1924). Though this reasoning has been justly criticized (4 PAGE, CoNTracts (1920) $\$ 2153$, n. 8 ), it seems a more logical application of the "completeness" standard than the doctrine which would require "completeness" to be ascertained without examining the alleged oral agreement, by the omission of which the writing is claimed to have been leit incomplete. The diffeulty lies in the inadequacy of "completeness" as a standard.

${ }^{13}$ See De LaSalle y. Guildford, L. R. 2 K. B. 215 (1901). 
ten," permitted the genuine supplementary oral bargains to be recognized and enforced. The rough-and-ready phrases about "varying the writing" of the seventeenth century English judges are elaborated in the appellate opinions of the American courts of the last hundred years, and these same formulas thus come to serve as the handles by which the appellate courts may revise the results reached both by judge and jury below. ${ }^{14}$ A judge who finds a line of opinions which repeat the formula that " $\Omega$ writing may not be varied by parol" and also another equally respectable parallel line of opinions repeating the refrain that "when a writing is partly written and partly oral, the oral part may be shown," 15 is in the situation, happy for the probable interests of justice in that individual case, where he can decide either way and for either decision can justify himself to counsel and parties by invoking an unimpeachable rule. ${ }^{10}$ Nevertheless, the doctrines of the previous cases, thus mutually inconsistent and "paired," have furnished him no more guidance than did the famous house-rule, "Do as you please," to the novices of the Abbaye-Thélème.

Likewise, convenient as this dark and tortuous ritualism was in enabling the trial judge to retain control over issues not safe to be trusted to the jury, yet the veiled inconsistencies and irrational mysticism of this protective phraseology which is draped around the written document begin to impart a sense of unensiness to Anglo-American legal scholars in the emerging rationalism of the latter half of the last century. For example, in 1876, Sir James Fitz-James Stephen, after having stated in traditional terms the rule against varying the writing, thus rationalizes the doctrine of "collateral" oral agreements: "The party may prove

\footnotetext{
14 See Green, JUdGe AND JURY (1930) c. 14.

15 Greenleaf apparently first made this lion and lamb lio down togothor. As appears from the following passage, courts gladly repeated the miraclo: "The rule is unquestioned that parol evidence is inadmissible to contradict or vary the terms of a valid written instrument: 1 GREENLEAF, Evidencu (16th ed. 1899) § 275 . But it is equally well settled that the rule does not apply 'in cases where the original contract was verbal and entire, and $a$ part only of it was reduced to writing.' Ibid. § 284, a; 2 PARsons ON CoNTRACTS (5th ed. 1866) 553, note." Cobb v. Wallace, 5 Coldwell 539, 544 (Tenn. 1868). A similar pairing of opposites is strikingly disclosed in the opinion of the court in Exum v. Lynch, supra note 12. The contradiction was bared in the following judicial comment: "If we may go outsido of tho instrument to prove that there was a stipulation not contained in it, and so that only part of the contract was put in writing, and then, because of that fact, enforce the oral stipulation, there will be little value loft in tho rule itself." Eighmie v. Taylor, 98 N. Y. 288, 294 (1885).

Io This availability on occasion of two categorically opposito rules has been often noticed. Pound, The Call for a Realist Jurisprudenoe (1931) 44 HARv. L. REv. 697, 704; Llewellyn, Some Realism about Realism, ibid. 1222; W. W. Cook, The Utility of Jurisprudence in the Solution of Legal Problems (1928) 5 LECTURES ON LEGAL Topics (N. Y. B. A.) 335.
} 
the existence of any separate oral agreement as to any matter on which a document is silent, and which is not inconsistent with its terms, if, from the circumstances of the case, the court infers that the parties did not intend the document to be a complete and final statement of the whole of the transaction between them...." 17

The greatest task of the new theory-builder is to tear away the shaky walls of the old structure. James Bradley Thayer, the great pioneer in the rationalization of the rules of evidence, struck his axe in deep at this point. Though he saw clearly enough "that the older" law and the older decisions... were often mainly concerned in keeping matters out of the hands of juries," ${ }^{1 s}$ he was offended at the device of treating the protective rule as an "evidence rule." This ran counter to the central theme around which Thayer arranged all his teaching about the subject of evidence-the dogma that a rule of evidence is not one which defines obligations but which operates to exclude relevant evidence. Doubtless this classification usually makes for clear thinking. It serves to segregate for unified treatment the rules of exclusion which are built around the weaknesses of juries from the mass of substantive rules which incidentally result in excluding evidence of transactions that they render ineffective. Doubtless, also, the parol evidence doctrine fails to fit into this category of rules of evidence with any comfort. Nevertheless, though excluded from the family fold of rules of evidence, it can claim common ancestry in distrust of the jury.

Thayer was not content with charging that the parol evidence rule was misbranded when called a rule of evidence. He tells us that it is a rule of the substantive law defining contracts, deeds, judgments, or the like. Doubtless, in a sense, this is true. What is the rule of substantive law which, as between prior oral expression and later written deed or contract, selects the effective part of the transaction? Wigmore, in one of the most brilliant chapters of his great treatise, shows the relation between the process which he calls "integration" and the whole body of doctrine relating to the creation of jural transactions generally. ${ }^{19}$ So far as any widely applicable modern principle may be stated, it is that the terms of the transaction (contract, deed, or the like) are to be obtained from the intention of the parties as revealed by their conduct and language. Among several expressions from which such an agreement or other jural

17 Stephen, Digest of the Lat of Evidence (5th ed. 1901) art 90.

18 Thayer, Preliminary Treatise on Evidence at the Common Latw (1898) 409.

195 Wigmore, op. cit. supra note 8, c. 86; cf. Strahorn, The Unity of the Parol Evidence Rule (1929) 14 MInN. L. REv. 20. 
act is sought to be derived, an earlier tentative expression will be rejected in favor of a later expression intended as final. This would be true obviously if both the earlier and the later expression were oral. ${ }^{20}$ It is but a simple application of this rationale, to say that where an earlier tentative oral expression is followed by a later writing, then if the writing was intended to supersede the earlier expression, the law gives it that effect. This, in effect, is the theory of "integration." It is simple and rational and sets up no special rule for writings different from that applicable to transactions wholly oral. Is it possible that to this clear residuum may be reduced the formidable parol evidence rule, of which Thayer said, "Few things are darker than this, or fuller of subtle difficulties"?

The writer takes leave to suggest that while this generalization that the later writing will supersede the earlier oral expression, if the parties so intended, is accurate enough, and is doubtless best classified as a rule of substantive law and not as a rule of evidence, yet it is not the most significant phase of the obscure and complicated technique for protecting writings which has traditionally gone by the name of the parol evidence rule. Indeed, the formula would, of itself, extend no special protection to writings at all: As before suggested, a later oral expression, if so intended, would as completely supersede all prior negotiations as an "integrating" writing would. So far as this formula suggests, the question of whether the writing was intended to supplant earlier expressions would be assumed to go, in case of dispute, unreservedly to the jury in the normal course. Such a picture of the parol evidence doctrine, it is submitted, throws the high-light upon its family resemblance to the substantive rules for the creation of jural acts, but leaves in the shadow the rugged features distinctive to and charncteristic of this phase of judicial administration at the common law. This throwing of light on the family relationship was a notable achievement, which rescued the. parol evidence doctrine from the dark avenues of mystery. There is danger that the peculinx, and probably valuable, function which it performs in giving a special protection to writings may be under-emphasized and neglected, and thus become atrophied and finally lost.

That function, of course, is procedural. It is the reservation in the trial judge of a special and added authority over the

${ }^{20}$ Compare the following passage from the judgment in Kain v. Old, 2 B. \& C. 627 (1824): "Where the whole matter passes in parol, all that passes may sometimes be taken together as forming parcel of the contract, though not always, because matter talked of at the commencoment of $\mathfrak{a}$ bargain may be excluded by the language used at its termination. But if the contract be in the end reduced into writing, nothing which is not found in the writing can be considered as a part of the contract." 
question: Was this writing intended by the parties to displace this asserted oral term or agreement, if there was any such oral expression? Thayer was entirely aware that the parol evidence doctrine had been used by the judges to serve this purpose, ${ }^{21}$ but his main preoccupation was with the pioneer job of driving the parol evidence rule out of the "evidence" fold. Wigmore explicitly recognizes this special allocation of authority to the trial judge,22 but he cites no decisions to the point and apparently treats it as a minor and incidental feature of the subject. Williston, in his lucid and realistic treatment of the matter, follows, in the main, the lines laid down by Thayer and Wigmore. Like them, he touches but casually this question of "Who decides whether the document was intended to supersede that alleged oral agreement?"- -a question which will be decisive of the result in most actual cases of competition between an alleged oral agreement and a written document. By couching his discussion of "collateral" oral agreenents in terms of "admissibility," ${ }^{23}$ however, he reverts to the earlier "rule-of-evidence" phraseology. He implies that the "court" passes on the question of whether the parties intended the signed document to displace the alleged oral agreement by the mechanism of determining, at the outset, whether he will permit the evidence of the alleged oral agreement to be considered by the jury at all.

Wigmore, after stating that this question of intent is for the judge-a proposition which in its frank and naked delegation of the decision of a fact-issue to the judge might cause uneasiness to traditional-minded courts-suggests, in tentative presumption-form, a formula which tends somewhat to narrow the factinquiry. He says:

"In deciding upon this intent, the chief and most satisfactory index for the judge is found in the circumstance whether or not the particular element of the alleged extrinsic negotiation

\footnotetext{
21 See THAYER, op. cit. supra note 18 , at $401,409$.

225 WIGMORE, op. eit. supra note $8, \S 2430$, at 308 : "Whether a particular subject of negotiation is embodied by the writing depcuds wwolly upon the intent of the parties thereto.... This intent must be sought where always intent must be sought (ante, $\S \S 42,1714,1790$ ), namely, in the conduct and language of the parties and the surrounding circemstances. . . . There is a preliminary question for the judge to decide as to the intent of the parties, and upon this he hears evidence on both sides; his decision here, pro or con, concerns merely this question preliminary to the ruling of law. If he decides that the transaction was covered by the writing, he does not decide that the excluded negotiations did not take place, but merely that if they did take place they are nevertheless legally immaterial. If he decides that the transaction was not intended to be covered by the writing, he does not decide that the negotiations did take place, but merely that if they did, they are legally effective, and he then leaves to the jury the determination of fact whether they did take place."

232 WILLISTON, CoNTRACTS (1920) §§ 638, 639.
} 
is dealt with at all in the writing. If it is mentioned, covered or dealt with in the writing, then presumably the writing was meant to represent all of the transaction on that element; if it is not, then probably the writing was not intended to embody that element of the negotiation." ${ }^{24}$

Williston makes an extremely significant contribution by formulating a still more flexible and usable rubric, as follows:

"The test of admissibility is much affected by the inherent probability of parties who contract under the circumstances in question, simultaneously making the agreement in writing which is before the court and also the alleged parol agreement. The point is not merely whether the court is convinced that the parties before it did in fact do this, but whether parties so situated generally would or might do so." ${ }^{25}$

This, as will be observed, is given as a test of admissibility, that is, of action by the judge. This formula is paraphrased in the Contracts Restatement, which provides that the writing does not displace the oral agreement if the latter is not inconsistent with the writing and is such "as might naturally be made as a separate agreement by parties situated as were the parties to the written contract." ${ }^{26}$

\section{III}

A recent Pennsylvania case, Gianni v. R. Russel \& Compuny, ${ }^{\text {ar }}$ is almost unique in that the court, in dealing with this problem made skillful use of the ideas of this modern group of law writers. A room in an office building in Pittsburgh was lensed, with the provision that it should be used "only for the sale of fruit, candy, soda-water," etc., and, further, "that the tenant is not allowed to sell tobacco in any form." The tenant contended that, in the negotiations for the lease, and as an inclucement to his signing, it was orally agreed by the landlord's agent that the tenant should have the exclusive privilege of selling soft drinks in the building. The tenant sued for damages for breach of the oral agreement, in that the landlord permitted others to sell drinks. At the trial, the agent denied that any such oral agreement was made. The tenant had judgment below. On appeal, the court, by Schaffer, J., said :

\footnotetext{
245 WIGMore, op. cit. supra note $23, \S 638$.

252 WiLlsToN, op. cit. supra note $23, \S 638$.

20 Contracts Restatement No. 5 (Am. L. Inst. 1928) $\$ 236$ (1) (b).

$27281 \mathrm{~Pa}$. 320, 126 Atl. 791 (1924); for an extensive collection of othor cases see Note (1931) 70 A. L. R. 752.
} 
"When does the oral agreement come within the field embraced by the written one? This can be answered by comparing the two, and determining whether parties, situated as were the ones to the contract, would naturally and normally include the one in the other if it were made. If they relate to the same subjectmatter, and are so interrelated that both would be executed at the same time and in the same contract, the scope of the subsidiary agreement must be taken to be covered by the writing. This question must be determined by the court.... We have stated on several occasions recently that we propose to stand for the integrity of written contracts.... We reiterate our position in this regard. The judgment of the court below is reversed, and is here entered for defendant."

This opinion signalizes a new judicial willingness to search for a sound engineering technique in dividing the load between judge and jury in law-suits where alleged spoken words are set up in rivalry with written words. It challenges us to an examination of the feasibility of some of the available expedients.

First, the crude, older method of choice by the trial judge between the rule against "varying, altering, or adding to, a writing," and the formulas for "incomplete writings" and "collateral contracts," with the real motives for the choice left almost inarticulate, while it furnished the needed protection to writings, is specious and outworn. It falsely couches in terms of a technical rule of exclusion of evidence a device for giving special power to the judge to determine at the threshold fact-questions (Was the oral agreement made? Was it abandoned?) upon which the genuineness of the alleged oral terms, as part of the final bargain, depends. ${ }^{28}$

Second, we may advocate the plan of resolving the whole matter into one of the application of the standard of expressed intent, with no special treatment for written transactions, except this, that the trial judge shall determine as a preliminary factquestion whether a given alleged oral agreement was intended by the parties to be abandoned when the writing was signed. This solution has the merit of comparative simplicity, welcome after a century of obscurantism about "contradicting" writings.

28 Compare the rule that when the genuineness of the writing itself is challenged all that the trial judge requires, before admitting the writing, is only a prima facie showing. If the adversary's evidence raises a dispute, the issue is for the jury. Hamsher v. Kline, $57 \mathrm{~Pa} .397$ (1868); Flournoy v. Warden, 17 Mo. 435 (1853). For discussions of the functions of judge and jury in dealing with fact-questions which condition the admissibility of evidence under technical rules of exclusion, see MIaguire and Epstein, Preliminary Questions of Fact in Determining the Admissibility of Evidence (1927) 40 HARv. L. REv. 392; Morgan, Functions of Judge and Jury in the Determination of Preliminary Questions of Fact (1929) 49 HARV. I. REV. 165. 
It has behind it the great authority of the Wigmore treatise. It presents these difficulties, however. In the first place, judges are reluctant to avow an assumption of control over the ascertrinment of intent, so traditionally associated with jury-responsibility in the fields of crime, tort and contract. It is significant that even the enlightened opinion in the Gianni case, though quoting approvingly from the section of the Wigmore treatise which contains the statement that the question is one of intent, and is for the judge to decide, does not quote that statement, but prefers rather to place the question in the judge's hands in terms of what would normally have been done by parties in these circumstances. A further, and overriding, objection is this: the intention formula leaves out of account the principle need for a special hand-on-the-rein by the judge. This need is that of striking down at the outset claims of oral variants on the writing, variants which in fact the judge believes never were entered into but are fabrications, designed or unconscious. As already suggested the real service of the parol evidence doctrine is here. Seldom from the cases does one gain the impression that the dispute is really over whether an admitted oral agreement was intended to be superseded by the writing. Where the adversary's position is to be gleaned from the report, which is surprisingly seldom, it appears most often that he denies that any such oral counter-agreement was ever entered into. Where the judge's real doubts are on this score, little help is derived from a formula which directs attention solely to whether - assuming it to have been made-the oral agreement was intended by the parties to be superseded. It is comparable to the situation where a judge is called on to consider whether a certain copy of a document meets the requirements of the best evidence rule, when the real issue is whether the original document from which it was copied is not itself a forgery.

But a third course naturally presents itself. Why set up any special safeguards here? Treat the question of the genuineness of the alleged oral agreement and that of the parties' intention to supplant it by the document, as other fact-questions are treated. Let the trial judge use the same machinery for control of the jury which he always has available. If, in his opinion, reasonable minds could reach but one conclusion from the evidence, he is empowered to withdraw that question from the jury. Perhaps if judges were called upon habitually to use this device in the speech-versus-document situation, it would lend itself readily enough to the adequate protection of written transactions from the vagaries of juries. As such situations offer themselves to the trial judge, however, one party testifies that an agreement outside the writing was made, and that it was understood that this outside agreement was to be binding, together with 
the writing. Naturally, a trial judge-especially a timid, elective one-would shrink from a ruling that reasonable men could not believe this direct assertion on the stand. We are here in the realm of the vaguest opinion, where every conclusion is overweighted with the individual experiences and preconceptions of its advocate. With due realization of this, the writer believes that the usual formula for jury-control is inadequate here, and that the traditional reservation of a.special and added power in the judge is desirable.

There remains a fourth expedient. As foreshadowed in the above discussion, the writer urges its claims as the most acceptably fashioned for use by our present judges with our present juries. The expedient suggested is this: Let the trial judge, after hearing the testimony as to the alleged oral agreement, including the evidence of substantiating circumstances, compare it with the terms of the writing, and if he consider's that it is one which parties situated as these were would "naturally and normally" have recited in the writing itself, had they made it and intended it to stand, then he will reject the evidence thus tentatively heard. On the other hand, if (in the terms of the Restatement) he concludes that the alleged oral pact is "such an agreement as might normally be made as a separate agreement by parties situated as were the parties to the written contract," then he will allow the evidence to go to the jury.:3 In this way, the argument on the objection or motion to exclude will be aimed at abstract impersonal probabilities, and the ruling will not brand any witness as a liar. He will still, if he admits the evidence and the proof is conflicting, submit to the jury the issues: was the oral agreement made as claimed, and, if so, was it intended to be displaced by the written terms? ${ }^{\circ}$

29 Of course, by familiar process, in transactions of standardized pattern and frequent recurrence in litigation, the judges narrow the range of judgment by seeking to treat the cases of each type uniformily. Thus, in a given jurisdiction, we find numerous such rules as that oral agreements to treat a deed as a mortgage may be shown, or that oral agreements that an indorser is to be treated as a co-maker, may, not. A similar crystallizing process, accompanied by a counter-process in which, from time to time, some of the crystals are dissolving again into fluid, is characteristic of the administration of justice under wide general concepts, such as "reasonable care," "fraud," "judicial power" and id omne gemus.

${ }^{30}$ Dean Hale suggests in the following passage still another possible device: "The basic evils of the rule in its present form are, first, that it is a pretense, and second, that the collateral inquiries which arise whenever it confronts the court are artificial, capricious and arbitrary. The cure. Let the parol evidence rule be phrased and operate as a rule of presumption. When the terms of an agreement have been reduccd to writing by the parties, let it be presumed that the writing contains with exactness and completeness all those terms, but allow this presumption to be overcome by clear and convincing proof to the contrary." Hale, op. cit. supra note 2 , at 122 . This leaves, however, the manner of jury-control 
The anæsthetic qualities of the language-technique about "contradicting," "admissibility," and "completeness" which the courts have inherited, and the pre-occupation of the great textwriters, Thayer, Wigmore, and Williston, with the substantive aspect of the parol evidence doctrine, have contributed to the almost complete absence in the reported appellate opinions of any real discussion of the practical administrative problem of division of power between judge and jury. Doubtless the traditional practice of handling the matter at the trial as one of admissibility, without any jury-intervention, has become so completely second nature to judges and lawyers that it would rarely raise a query. Certainly, the appellate opinions almost universally assume that there is no fact problem but solely a legal point as to admissibility of evidence under a technical rule. In the rare instances of attempts by counsel to invoke a jury hearing on some issue relating to the oral agreement, or of claims . on appeal that the trial judge has improperly checked resort to the jury, the appellate courts have, in perhaps a majority of cases, said that the question of whether the writing "expressed the whole agreement," or was "complete," ${ }^{31}$ is for the trial judge.

An early and unequivocal pronouncement is that of the Now Jersey court in Naumberg $v$. Young..$^{32}$ In that case a tenant of a factory building sued the landlord for breach of an oral guaranty that the engine and boiler in the leased building were in repair and were adequate for the tenant's business. The trial court heard this evidence, but, it appearing that there was a written lease which was silent on the subject, the plaintiff was non-suited. In affirming this result, the upper court, in reference to the parol evidence doctrine, said:

"Undoubtedly this rule of evidence presupposes that the prrties intended to have the terms of their agreement embraced in the written contract. If it was designed that the written contract should contain only a portion of the terms mutually agreed upon, and that the rest should remain in parol, the parties have not put themselves under the protection of the rule. But in what manner shall it be ascertained whether the parties intended to express the whole of their agreement in the written contract? The question is one for the court, for it relates to the admission or rejection of evidence." "s3 [italics mine.]

somewhat uncertain. Must the evidence be "clear and convincing" to tho judge before he may admit the evidence of the outside oral expressions for consideration by the jury, or should he admit it for jury-appraisal, simply instructing them not to act on it unless "clear and convincing"?

31 Of course, these are alluringly simplified ways of saying that tho parties have intended to supersede the oral agreement, if made, with tho document.

3244 N. J. L. 331 (1882).

33 Ibid. 338. 
The Supreme Court of the United States plumped decisively on the same side, ${ }^{3 s}$ and dicta or decisions upholding the power of the trial judge to determine whether the writing is "complete," "contains the entire agreement," or was intended to supersede the oral negotiation, have come from Pennsylvania, 3 Connecticut, ${ }^{36}$ and California.. ${ }^{37}$ Other cases are not classifiable

\&4 Seitz v. Brewers' Refrig. Co., 141 U. S. 510, 517, 12 Sup. Ct. 46,48 (1891) (Oral warranty of machinery asserted against written contract of sale, which contained no warranty. The trial court directed a verdict against the claim of warranty. Affirmed. "Whether the written contract fully expressed the terms of the agreement was a question for the court ..."). The court did not mention an interesting decision of the previous year (Bank of British North America v. Cooper, 137 U. S. 473, 11 Sup. Ct. 160), in which the question arose at the trial whether certain cable transfer-bills given by a bank to a customer were decisive as to the terms of the agreement. On appeal, the court said: "Such bills may or may not be the contract. They may be nothing more, and intended to be nothing more, than memoranda or receipts. Whether they are the entire contract or simply in the nature of receipts is not a question of law for the court, but one of fact for the jury." Watkins Salt Co. v. IIulkey, 225 Fed. 739 (C. C. A. 2d, 1915), follows the Seitz case. Of similar effect is South Florida Lumber Mills v. Breuchaud, 51 F. (2d) 490,493 (C. C. A. 5th, 1931), wherein it was held that the trial judge correctly declined to submit to the jury the question whether earlier oral agreements were superseded by the writing. The interesting opinion, by Hutcheson, circuit judge, adopts the "intention" test on the authority of the Wigmore treatise, and says that its application is "primarily" for the trial court.

35 Gianni v. Russell, supra note 27.

36 Brosty v. Thompson, 79 Conn. 133, 136, 64 Atl. 1, 2 (1906) ("For the trial court," but it does not appear whether there was a jury); Pyslioty v. Sobusiak, 109 Conn. 593, 145 Atl. 58 (1929).

37 Harrison v. MTcCormick, 89 Cal. 327, 26 Pac. 830 (1891) (Tritten contract for sale of "Montana lump" coal, with no mention of sample. Defendant, when sued for price, seeks to show that it was orally agreed that the coal would equal coal previously furnished. Admitted. Judgment for defendant. Held, error: "The question whether a writing is upon its face a complete expression of the agreement of the parties is one of law for the court ..."); Thoroman v. David, 199 Cal. 386, 249 Pac. 51:3 (19213) (A contract to sell house and land was in the form of written escrov instructions to a title guaranty company. There was no reference in the writing to the furniture in the house. Plaintiff, the purchaser, sued for the furniture. The trial judge admitted plaintiff's testimony that the furniture was orally agreed as included. Defendant's witnesses testified in denial. At the trial, apparently without a jury, the court found that the furniture was included. Held, on appeal, that the evidence of the cral agreement was inadmissible, and that the finding was unsupported. The court quotes the above excerpt from the Harrison opinion); Stephan $v$. Lagerqvest, 52 Cal. App. 519, 199 Pac. 52 (1921) ("Whether writings which pass between parties contain the complete contract which they have made is a question of law, and is to be determined from the face of the instruments ..."). Seemingly contra, is the language of the opinion in Luitweiler Co. v. Ukiah Co., 16 Cal. App. 198, 207, 116 Pac. 707, 711 (1911), affirmed by the Supreme Court, without adopting the opinion, 16 Cal. App. 198, 116 Pac. 712 (1911). 
with entire certainty but seem to lend countenance to this view, ds

Perhaps it is not fanciful to detect the strongest leaning in this direction in those courts which have been least affected by the Jacksonian cult of judicial elections for short terms. At all events, the earliest expression to the contrary comes from the vicinity of the Hermitage. In $C o b b v$. Wallace, ${ }^{32}$ an action was brought for conversion by the wrongful detention of a coal barge. The barge belonged to the plaintiff, who loaded it with coal and sold the coal to the defendants. Defendants gave a brief receipt for the coal and barge, which contained a promise that the defendants would pay $\$ 3$ per day "until the barge is returned." The evidence showed that it had been orally agreed that the barge should be returned as soon as the coal was unloaded at destination. Instead, the defendants kept the barge and hired it out to others. The trial judge charged the jury that the oral contract "could not be looked to," and that under the terms of the writing "the contract for the use of the barge would not be terminated until the defendant so elected." On appeal, the court, in the course of an extended opinion, in which several errors were pointed out, said: "The plaintiffs had the right to have the question, whether the parol contract had been made as alleged, and whether the writing introduced embraced all the terms of such previous parol contract, [italics mine] submitted to the jury; and it was error in the court to withdraw this question of fact from the jury, and to decide it itself." "The receipt was apparently intended as a mere partial memorandum, so that, in any view, it seems that the trial judge erred in instructing the jury to disregard the alleged oral agreement. of course, if the evidence of the oral agreement was competent, but the making of the oral agreement was disputed, it was for the jury to determine that dispute. But the italicized phrase is the first suggestion (so far as the writer has discovered) that the jury is to decide, free from preliminary intervention by the trial judge, whether the writing was intended to supplant all prior negotiations. ${ }^{40}$ How far the court meant to go in this decision

${ }^{38}$ Offutt v. Doyle, 135 Ky. 296, 122 S. W. 156 (4) (1909); Ft. Worth \& D. C. Ry. v. Wright, 30 Tex. Civ. App. 234, 70 S. W. 335 (1902); Standard Scale \& Supply Co. v. Baltimore Enamel and Novolty Co., 136 Md. 278,-110 Atl. 486 (1920). See also McNeeley v. McWilliams, 13 Ont. App. Rep. 324, 330 (1886), and the discussion of this and other Canadian cases, by Professor MacRae, in 4 Canadian Encyclopedic Draest (Ont. ed. 1928) 803.

305 Coldwell 539 (Tenn. 1868).

10 The same confused assumption that the jury must determine both whether the writing was exclusive, and, if not, whether the alleged oral agreement actually was made, appears in a later Tennessee caso. Hinos v. Willcox, 96 Tenn. 148, 159, 33 S. W. 914, 916 (1896) ("The question as to whether the entire contract was reduced to writing, or an indepondent collateral agreement was made, was a question of fact, and whero 
is questionable. It gave only a side-glance at this minor point, unnecessary as it was to the disposition of the case.

As is customary, the idea is uncritically adopted by the encyclopedias, ${ }^{41}$ and from them in a sprinkling of judicial opinions. 42 Conceivably, all that some of the opinion writers who place this question in the jury's hands mean to suggest is that after the judge has approved the oral agreement as one which might normally stand with the writing, he should still leave to the jury to say whether these parties actually did intend to supersede the oral agreement. If so, they are unobjectionable. Always, however, the treatment is casual, the traditional and seemingly contrary view is ignored, and the extent to which the courts mean to go in turning the question over to the jury is beclouded by the language that the jury must say whether the writing "contains the entire agreement." This may mean, whether the writing was intended to supersede the oral agreement or, less probably, it may mean, whether there was in fact any oral agreement at all outside the writing.

In this comparison, the balance of clear-cut judicial opinion would seem to incline toward the traditional practice, approved by the Federal Supreme Court. But, at best, the handling of the question is haphazard and oblique.

A rehash of contradictory clichés, worn smooth with unthinking repetition since they were first culled from the pages of Greenleaf, is the substitute which most opinions offer for fresh and realistic consideration of the problem. In this unsatisfactory state of the judicial pronouncements, it seems highly desirable that the current draft of the restatement of the doctrine by the American Law Institute should be amended, to make clear the function of the judge in its administration. ${ }^{33}$

there was any evidence to sustain the contention, it was a matter for the jury to determine, and not for the court.").

41 E.g., 6 R. C. L. 55; 22 C. J. 1291.

42 Gordon v. Curtis Bros., 119 Ore. 55, 248 Pac. 158 (1926). In Hirsch v. Salem Mills Co., 40 Ore. 601, 601, 67 Pac. 949, 68 Pac. 733 (1902), the question of whether the oral contract survived the writing was held to be one of "fact" not determinable on the pleadings, but only "by a trial and upon testimony," but this does not quite mean that the jury must decide it. Two interesting MIassachusetts cases may be thought to indicate a tendency toward the enlarged view of the jury's function, but in Thomas v. Barnes, 156 Mass. 581, 31 N. E. 683 (1892), the writing was not signed by the party who asserted the oral contract, and in Corey v. Woodin, 105 Mass. 464,81 N. E. 260 (1907), the question of intention to supersede the oral contract with the writing, which was treated as a jury-question, related to a novation rather than an "integration."

13 Perhaps the draft section of the Restatearent of Contracts, as quoted above (p. 376), might appropriately be revised by adding the words in brackets: "Sec. 236. An oral agreement is not superseded . . . by a subsequent. ... integration ... if the agreement ... (b) is such an 
If the parol evidence doctrine is to be administered chiefly by juries and not by judges, its special protection for written transactions dwindles and fades. Perhaps such special protection is no longer needed. The telephone, and the urgent call for high speed in certain types of important transactions, such as security trading, have accustomed business men to rely upon word-of-mouth, and to dispense with the safeguard of writing.44 And conceivably, jurors, in this day of universal education, are more able and willing to sift critically and intelligently testimony about oral negotiations preceding a writing. Perhaps, on the contrary, it might be thought that the jury, even assuming a personnel more intelligent than that of fifty years ago, is less adequate than ever, in view of the increased demands of presentday litigation. Certainly, the jury was never lower in general esteem. ${ }^{45}$ Again, while business men more often make great

agreement as [in the opinion of the trial judge] might naturally bo mado as a separate agreement. ..."

44 This is suggested in a letter from Professor Nathan Isancs, from which I take the liberty of quoting: "In the first place, the business man of today relies and must rely less and less on writing than ho did oven fifty years ago. The telephone has something to do with this changa, but a more important factor is the speed required in modern business. It is true that our facilities for rapid writing have increased, but our need for rapidity in transactions has increased much more rapidly. The rosult ds that the business man is accustomed to seeing millions of dollars worth of securities change hands on the stock exchange without the scratch of a pen. But this is not the whole or even the most important part of tho story. Even where writing is resorted to two forces have conspired to prevent the writing from containing or even purporting to contain the "whole" contract. One of these is the growing complexity of transactions, and the other is a phase of the speed already mentioned which shows itself in the brevity of business letters and other memoranda.

"To fill the gaps which necessarily result in the modern business contract, we resort more and more to the standardizing elements (customs, statutes, rules of trade associations, chambers of commerce, exchanges), but a great many blanks still remain to be filled in by oral understanding. Tho real danger therefore to the business man that comes from a strict onforcoment of the parol evidence rule, is that as contracts are made today ossential parts are in danger of being excluded. In other words, I mean to suggest that however fitting the parol evidence rule may have been when it grew up, it is not in strict accord with the needs of business todny. It is a gratuitous assumption that where people take the trouble to reduco their contract to writing their motive is to prevent explanations-oven contradictory explanations-from entering into the situation. On tho contrary, the motive for writing may be the very simple motive of satisfying the need of quick communication or of making a memorandum in such $\mathfrak{a}$ form as to fit into the plan of a business for having the memorandum ated on, or it may be some quite different motive."

${ }_{45}$ See, as reflections of some current opinion, GREEN, JUDGE AND JURY (1930) c. 15; Frank, LaW AND the Modern Mind (1930) 179, 180. Dven trial lawyers in active practice before juries are occasionally voicing skepticism about the value of the juxy-system. F. H. Peterson, Commonts on Trial by Jury (1926) 10 LAW Notes 188; T. D. Samford, How to Pioli a 
decisions orally, because of the urge for speed, yet today, more generally than ever before, business men, when there is no cry for haste, reduce their transactions to writing.

Around considerations such as these should center the discussion which will shape the future evolution of the parol evidence doctrine. The protection afforded by that doctrine will wax or wane as the judge or the jury takes the upper hand in its administration. The presently fashionable portrayal of the doctrine throws the spot-light upon its obvious substantive aspect. The procedural side, with its apportionment of duties between the bench and the jury box, must be rescued from the shadows.

Jury (1928) Proc. ALA. ST. BAR ASS. 135, 143; MTCCall, ilid. 85, 36; STALmaster, What Price JURY Trials? (1931). 